\title{
Sustainable Biological Ammonia Production towards a Carbon-Free Society
}

\author{
Yukio Watanabe ${ }^{1}$ D , Wataru Aoki ${ }^{2}$ and Mitsuyoshi Ueda ${ }^{2, *}$ \\ 1 Biotechnology Research Center, Department of Biotechnology, Toyama Prefectural University, \\ Toyama 939-0398, Japan; y-watanabe@pu-toyama.ac.jp \\ 2 Graduate School of Agriculture, Kyoto University, Kyoto 606-8501, Japan; aoki.wataru.6a@kyoto-u.ac.jp \\ * Correspondence: ueda.mitsuyoshi.7w@kyoto-u.ac.jp; Tel.: +81-075-753-6112
}

check for

updates

Citation: Watanabe, Y.; Aoki, W.; Ueda, M. Sustainable Biological Ammonia Production towards a Carbon-Free Society. Sustainability 2021, 13, 9496. https://doi.org/ $10.3390 /$ su13179496

Academic Editors:

Peyman Abdeshahian,

Felipe Antonio Fernandes Antunes,

Avinash P. Ingle

and Silvio Silvério da Silva

Received: 30 June 2021

Accepted: 20 August 2021

Published: 24 August 2021

Publisher's Note: MDPI stays neutral with regard to jurisdictional claims in published maps and institutional affiliations.

Copyright: (c) 2021 by the authors. Licensee MDPI, Basel, Switzerland. This article is an open access article distributed under the terms and conditions of the Creative Commons Attribution (CC BY) license (https:// creativecommons.org/licenses/by/ $4.0 /)$.

\begin{abstract}
A sustainable society was proposed more than 50 years ago. However, it is yet to be realised. For example, the production of ammonia, an important chemical widely used in the agriculture, steel, chemical, textile, and pharmaceutical industries, still depends on fossil fuels. Recently, biological approaches to achieve sustainable ammonia production have been gaining attention. Moreover, unlike chemical methods, biological approaches have a lesser environmental impact because ammonia can be produced under mild conditions of normal temperature and pressure. Therefore, in previous studies, nitrogen fixation by nitrogenase, including enzymatic ammonia production using food waste, has been attempted. Additionally, the production of crops using nitrogen-fixing bacteria has been implemented in the industry as one of the most promising approaches to achieving a sustainable ammonia economy. Thus, in this review, we described previous studies on biological ammonia production and showed the prospects for realising a sustainable society.
\end{abstract}

Keywords: ammonia; sustainable carbon-free society; nitrogenase; metabolic engineering; cell surface engineering

\section{Introduction}

Recently, the realisation of a sustainable society has been desired. The global environment is rapidly deteriorating due to global warming and ocean acidification caused by the massive consumption of fossil fuels and deforestation. Therefore, to improve this situation, Sustainable Development Goals have been declared, and not only researchers but also governments and corporations of various countries are taking great interest in improving the global environment [1,2]. Furthermore, to achieve a carbon-free society, we should reduce our dependence on fossil fuels for energy production and increase the use of renewable resources, such as geothermal, hydro, solar, and wind power [3-6]. Interestingly, wind-power generation has recently received the most attention and wind turbine generators are spreading greatly [7]. Biomass (e.g., perennial plants, forestry residues, and municipal solid waste (MSW), such as food waste and algae) is also recognised as an effective carbon-neutral resource for reducing greenhouse gas (GHG) emissions. However, the energy production efficiency of these technologies varies with the weather, time, and location. Additionally, energy supply tends to be unstable. Therefore, the development of a more stable energy supply method is desired [8-11].

In addition to energy production, the production of key chemical substances in various industries should also be sustainable, particularly that of ammonia, an important chemical substance in various industries. More than $75 \%$ of ammonia is used as fertiliser in the agricultural sector. Ammonia is also widely used in the steel, chemical, textile, and pharmaceutical industries. Therefore, the synthesis of primary amines from ammonia contributes to produce important key chemicals for manufacturing dyes, pesticides, and pharmaceuticals in the chemical industry [12-17]. Ammonia is also expected to be used as fuel $[6,8,18-23]$, as $1 \mathrm{~mol}$ of ammonia contains $1.5 \mathrm{~mol}$ of hydrogen. Thus, due to its high 
volumetric hydrogen $\left(121 \mathrm{~kg} \mathrm{~m}^{-3}\right)$ and weight fractions $(17.8 \mathrm{wt} \%)$, ammonia should be used as an efficient carrier of hydrogen. Additionally, ammonia can easily be transported in liquid form at temperatures below $-33.4^{\circ} \mathrm{C}$ and atmospheric pressure or room temperature of $8.5 \mathrm{~atm}$. Additionally, the flammability range of ammonia in air is $16 \%$ to $25 \%(v / v)$, making it safer to transport than hydrogen [24-26]. Moreover, direct ammonia fuel cells can efficiently convert ammonia into energy for vehicles, thereby making it increasingly feasible to develop ammonia-fueled vehicles [27,28]. Therefore, the infrastructure for storing and transporting ammonia has already been established and therefore using these infrastructures in a society based on ammonia energy can be realised quickly.

Fifty-five percent of all ammonia produced is conducted using the Haber-Bosch process [29]. It is estimated that the Haber-Bosch process uses about 2-3\% of the energy used worldwide because it requires the breaking of the triple bonds of nitrogen molecules at high pressure $(150-350 \mathrm{~atm})$ and high temperature $\left(350-550{ }^{\circ} \mathrm{C}\right)[29,30]$. Therefore, the development of new catalysts that catalyse reactions under mild conditions is desirable for realising a sustainable society [29-33]. For example, the use of Ru catalysts is being considered. However, $\mathrm{Ru}$ is much more expensive than conventional iron catalysts and there are only about 10 ammonia synthesis plants in the world that use Ru-based catalysts [33]. More recently, attempts have been made to develop metal catalysts that mimic the active centres of nitrogenases [34,35]. The most successful example is the molybdenum-based catalyst of samarium diiodide dissolved in alcohol or water [36]. However, although nitrogen fixation by this catalyst has been achieved at room temperature and pressure, further research should improve its reaction rate.

Recently, biological approaches have also attracted much attention for sustainable ammonia production [37-39]. These biological approaches allow producing various substances under mild conditions [40-44]. So far, biological approaches have as well been successfully used to produce energy, such as alcohol and hydrogen, making use of raw materials such as glycerol, sugar, and fatty acids on a commercial scale [40-47]. In ammonia production, the use of nitrogen fixation by nitrogenase and enzymatic production methods from food waste are beginning to be actively studied. These approaches should influence sustainable ammonia production in the future. Therefore, this review introduced the most recent studies on biological ammonia production and described the prospects for realising a sustainable society (Figure 1).
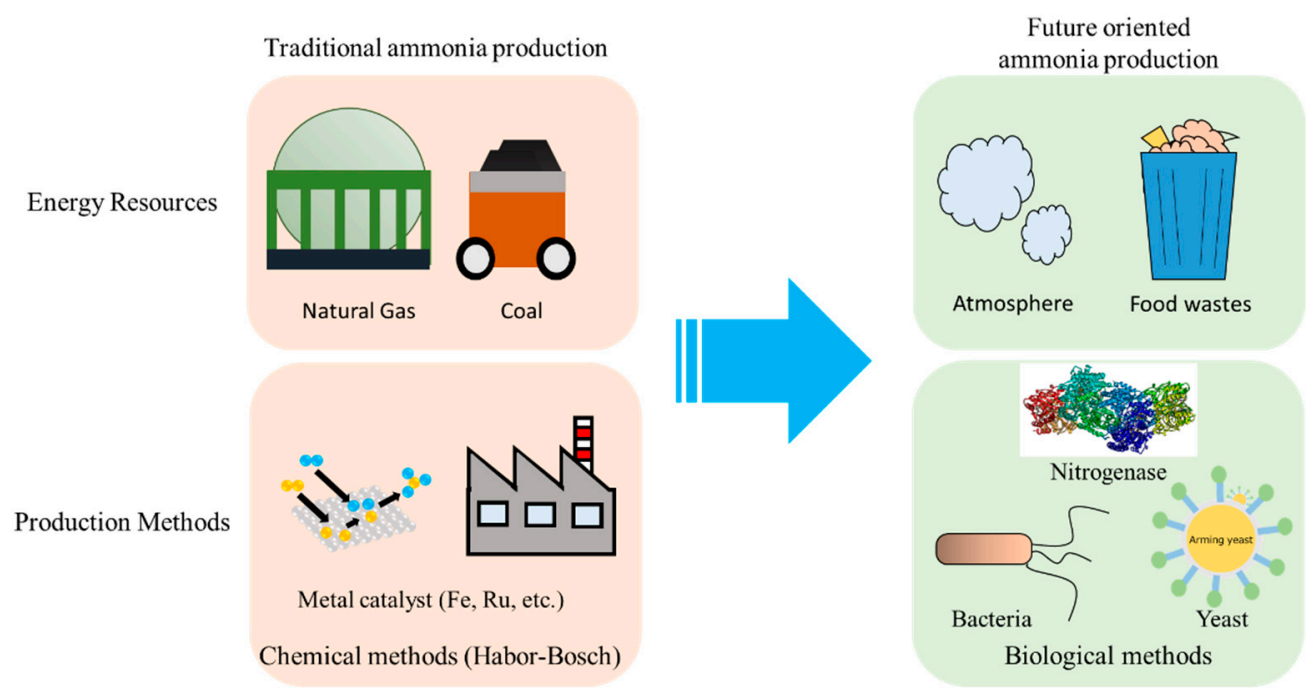

Figure 1. Comparison between traditional and future-oriented methods for ammonia production toward a carbon-free society. The figure of nitrogenase was generated from PDB ID code 1N2C by using UCSF Chimera [48,49]. 


\section{Ammonia Production Using Nitrogenase}

In contrast to the Haber-Bosch process, which requires high temperature and pressure conditions, diazotrophic bacterial nitrogenases can produce ammonia at ambient temperature and pressure conditions [50]. Rhizobia, a type of diazotrophic bacteria, is a group of Gram-negative bacteria that includes Alphaproteobacteria and Betaproteobacteria [51,52]. These rhizobia form nodules in the roots and stems of their host legumes and fix nitrogen [51,52]. Furthermore, the amount of nitrogen fixed by cultivating forage legumes reaches $2.4 \times 10^{12} \mathrm{~mol}$ of Nitrogen annually $[53,54]$. Thus, it is estimated that about $21 \%$ of the nitrogen fixed on earth is so by nitrogenases of nitrogen-fixing bacteria [31].

Nitrogenases are enzymes that produce ammonia from nitrogen molecules in an ATPdependent manner (Figure 2a) [49]. The kinetics of nitrogenase are kcat $/ \mathrm{km} \sim 10^{4} \mathrm{M}^{-1} \mathrm{~s}^{-1}$, whereas its turnover is $1 \mathrm{~s}^{-1}$ [55]. Although the reaction rate of nitrogenases is slower than that of other enzymes, such as ribosomes and DNA polymerases, it is recognised as an excellent enzyme in that it can cleave the triple bond of nitrogen molecules at room temperature and normal pressure $[56,57]$. Therefore, to realise a carbon-free society, many studies have been conducted on nitrogenases from both basic and applied aspects [50,58-60]. Numerous studies have elucidated the structure-activity relationship of nitrogenases [58,61,62]. They have found that the active centre of nitrogenases was identified at the interface of a tetrameric structure comprising two molecules each, NifD and NifK [63]. These two proteins use metal atoms, and the $\mathrm{MoFe}, \mathrm{FeFe}$, and VFe cofactor types exist. Furthermore, the ATP-binding site is located at the dimeric interface of NifH [63]. In 1992, the entire structure of the MoFe-type nitrogenase protein complex derived from Azotobacter vinelandii was first characterised by X-ray crystalography [64]. Later, the resolution was improved to $1.16 \AA$ from $2.7 \AA$, and the structure of the complex [8Fe:7S] iron-sulfur cluster was precisely elucidated [65].

(a)

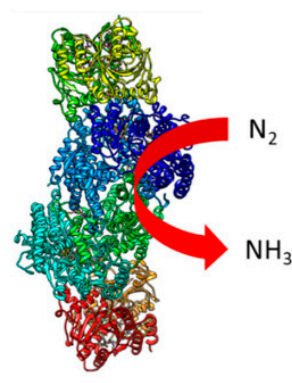

(b)

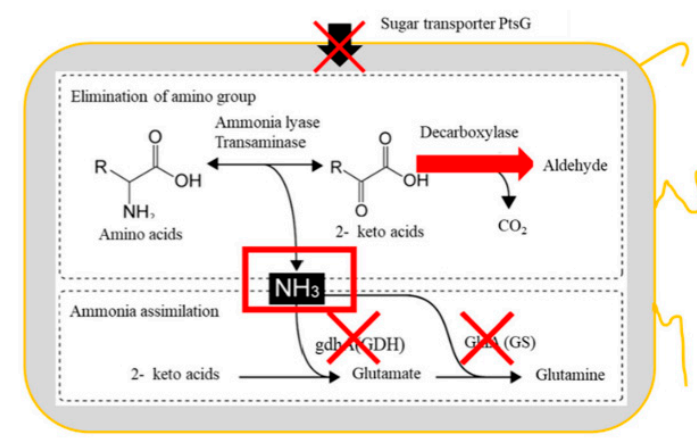

(c)

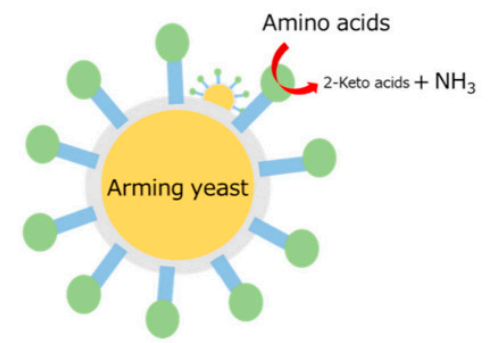

Figure 2. Methods for ammonia production: (a) crystal structure of the nitrogenase complex (PDB ID code $1 \mathrm{~N} 2 \mathrm{C}$ ), the model was generated from PDB ID code $1 \mathrm{~N} 2 \mathrm{C}$ by using UCSF Chimera and the ammonia production from $\mathrm{N}_{2}$ [48,49]; (b) ammonia production from nitrogen-based media, including sugar. Red crosses, red arrows, and red boxes indicate knockout of genes, overexpression of genes, and the product of interest, respectively; (c) ammonia production using cell surface engineered yeast from amino acids contained in enzyme-treated soybean residues. Amino acids are converted into 2-keto acids and ammonia by using L-amino acid oxidase-displaying yeast. 
Therefore, although nitrogenase is an extremely complex machinery, and thus difficult to engineer, though some important achievements exist. For example, attempts to express the nitrogenase complex of the nitrogen-fixing bacterium A. vinelandii in Escherichia coli have been successful, and the minimal set of genes required for nitrogen fixation has been identified. The Fe-type nitrogenase complex from $A$. vinelandii, originally composed of 21 subunits, the nitrogenase complex can be actively expressed by simply incorporating only 10 genes into E. coli [66]. Furthernore, the Fe-type nitrogenase from Paenibacillus sp., which consists of 20 subunits, functions with a set of nine genes; however, the activity of the reconstituted nitrogenase was close to $10 \%$ that of the wild type [67]. In further studies, adding NifSU and pfoABfldA to this minimal gene set yielded 50.1\% of the wild-type activity [68]. Furthermore, an attempt has been made to reconstitute 14 nitrogenase-related genes from Klebsiellaoxytoca by combining them into five gene cassettes and cleaving them with tobacco etch virus-derived proteases after expression. This combination has led to creating E. coli that can grow under anaerobic conditions using only nitrogen molecules as a nitrogen source [69]. Moreover, in yeast, eukaryotic organisms, NifH and NifM, which are nitrogenase subunits, were localised in the mitochondria, purified, then mixed with other subunits purified from E. coli to reconstitute an active nitrogenase [70]. Researchers also isolated the active form of AnfH, which uses cheaper Fe instead of NifM, the rare earth $\mathrm{Mo}$, and reconstituted the active nitrogenase by mixing it with other subunits [71]. NifB is a subunit required for forming MoFe clusters in the nitrogenase active centre; however, this protein was not well expressed in the mitochondria of budding yeast [72]. Therefore, all $28 \mathrm{NifB}$ genes from various nitrogen-fixing bacteria were introduced into yeast, after which the evaluation of all 62 genes with different expression levels was conducted [73]. As a result, NifB from the archaea Methanocaldococcus infernus or Methanothermobacter thermautotrophicus became successfully active in the mitochondria of budding yeast [73]. Further studies have also attempted to express nitrogenase subunits within plant mitochondria. This study found that NifF, M, N, S, U, W, X, Y, and Z can be expressed in soluble forms, whereas, NifB, $\mathrm{E}, \mathrm{H}, \mathrm{J}, \mathrm{K}, \mathrm{Q}$, and $\mathrm{V}$ were insoluble. It was also found that the nitrogenase activity of NifM was reduced to $10 \%$ of the control because of the N-terminal processing (MTP) that occurs during mitochondrial transport [74]. Furthermore, the NifD protein itself contains an MTPrecognition sequence, which is subject to processing, thereby making functional expression difficult. However, R98 has been identified as a key mutation for this cleavage, and an R98P mutant that is resistant to processing and retains high levels of activity in the mitochondria has been obtained [75]. Another study found that the Y100Q mutant was also resistant to processing within the plant and yeast mitochondria [76]. In their search for efficient NifH expression, the authors expressed 32 types of $\mathrm{NifH}$ in tobacco and yeast mitochondria and found that NifH from the thermophilic bacterium Hydrogenobacter thermophilus (Aquificae) in particular was produced in the most active form. Additionally, the highly temperature in the mitochondria controls itself [77]. Thus, with the finding that the temperature in the mitochondria can reach $50{ }^{\circ} \mathrm{C}$, the expression of nitrogenase subunits from thermophilic bacteria should be one of the approaches of future interest [77]. Additionally, with further research, it might be possible in the future to construct functional nitrogenases in plant cells and create a practical crop that can fix nitrogen by itself [78]. Recently, researchers have succeeded in heterologously expressing a nitrogenase that is active within the chloroplast of the cyanobacterium Synechococcus elongatus PCC7942, and have also succeeded in creating algae that can fix nitrogen using energy from photosynthesis [79].

Nitrogenases have the two following major problems: low stability and easy denaturation by oxygen, which should be solved [50]. Therefore, in a study to search for a highly stable nitrogenase, nitrogen fixation at $92{ }^{\circ} \mathrm{C}$ was detected using archaea isolated from hydrothermal vents in the deep sea [80]. Additionally, various methods, such as pyrene hydrogel, redox polymer, encapsulation, and nanocoating known as immobilisation supports contributed to enzyme stabilisation, and studies using carbon nanotubes for nitrogenase stabilisation exist [81,82]. Additionally, several mechanisms that protect nitrogenases from oxygen exist as well. For example, it has been shown that the shethna 
protein, which functions as a lid on the oxygen binding site, protects nitrogenases from oxygen [83]. Ferredoxin-NADPH oxidoreductase (FNR) and similar proteins from chloroplasts, root pigments, and mitochondria were also expressed as alternative enzymes to NifF, which functions as an electron donor for nitrogenase, and found that the FNR-ferredoxin module in chloroplasts and root pigments supported the activity of MoFe-type and FeFetype nitrogenases [84]. Furthermore, research on legume constructs symbionts, such as Rhizobium leguminosarum, is also ongoing, with a study on the comprehensive analysis of genes involved in symbiosis. A candidate gene set made up of 603 genes has been listed as symbiosis-related genes, and 146 of them were important genes for root development with nitrogen-fixing bacteria [85]. Moreover, regarding the function of leghemoglobin, which is highly concentrated in legume rhizoids, a comparison of a CRISPR/Cas9-generated knock out strain of the leghemoglobin-encoding gene and the wild-type strain revealed that the absence of this gene causes mitochondrial dysfunction and was involved in posttranslational modifications of heme synthesis [86]. Therefore, by elucidating the symbiotic mechanisms of nitrogen-fixing bacteria in these studies, the future creation of rhizobia capable of symbiosis with various crops is possible. There exists a nitrogen-fixing alga, Leptolyngbya boryana, with a heterocyst is enabled, which will solely be used for nitrogen fixation. The nitrogenase genes of this alga have been studied as well. For example, it is known that when nifZ is deleted, nitrogenase activity is reduced to less than $10 \%$, resulting in poor growth of the alga. It has also been shown that loss of nifP causes poor growth and a reduction in nitrogenase activity to $22 \%$ [87]. Thus, a closer look at the mechanisms involved in oxygen protection in this alga is proposed to lead to the future use of nitrogenases less susceptible to inactivation when exposed to oxygen.

Recently, it has been disclosed that various companies, such as Gingko Bioworks and Pivot Bio, Inc., are attempting to use nitrogen-fixing microorganisms in industrial applications. A proven study developed by Pivot Bio, Inc. used genetically engineered gram-positive nitrogen-fixing bacteria of the genus Enterobacter [88]. These bacteria had a low intracellular glutamine concentration due to the reduced expression of the ammonium assimilation-related transcription factor gene, GlnR. Thus, by increasing the intracellular glutamine, this bacterium synthesised more ammonia, which is the raw material for glutamine in the presence of nitrogenase than the wild strain [88]. Additionally, by preinfecting the corn plant (Zea mays) seeds with these bacteria, a stable supply of nutrients was provided because washing away by rain did not occur [88]. Therefore, this technology has been field-tested, and a report in 2020 showed that it resulted in an average yield increase of about $9 \%$ in the cultivation of corn than for use in chemical fertilisers alone [89].

\section{Ammonia Production by Metabolic and Cell Engineering}

Recently, there have been attempts to produce ammonia from sources other than atmospheric nitrogen molecules. For example, attempts were made to recover ammonia from the nitrogen contained in amino acids derived from proteins in food waste. Therefore, in this section, we introduce the possibility of producing ammonia from amino acids and food waste using microorganisms modified by metabolic and cellular engineering.

The production of food waste has recently been increasing, and according to the Food and Agriculture Organization (FAO), it accounts for one-third of all food produced. This means that about 1.4 billion hectares of fertile land ( $28 \%$ of the world's agricultural area) are used to produce food that is lost or wasted yearly [90]. For example, it has been reported that the annual amount of urban food waste in Asian countries should increase from 278 million tonnes to 416 million tonnes between 2005 and 2025 [91]. Specific examples of food waste are fruits, such as grapes, apples, and citrus fruits, vegetables, such as potatoes, tomatoes, carrots, and onions, as well as staple food-derived waste, such as legumes and rice bran [92]. Therefore, attempts to convert this waste into high value-added compounds should be effective for realising a sustainable society, and recently, many attempts have been made to produce useful compounds from food waste. 
Among the best-known uses of food waste is anaerobic digestion [11]. This type of digestion can be divided into three major stages: enzymatic hydrolysis, acid production, and gas production $[93,94]$. Hydrolysis breaks down polymer molecules, such as carbohydrates and proteins, that cannot penetrate cell membranes, into monomers mainly by streptococci and Enterobacter [11]. Next comes acid production, which is a type of digestion where hydrolysis products are fermented into volatile fatty acids, such as acetate, propionate, butyrate, valeric acid, and isobutyrate, along with carbon dioxide, hydrogen, and ammonia. Acetic acid bacteria mainly produce these volatile fatty acids [95]. Here, acetic acid is also produced by Syntrophomonas and Syntrophobacter, and is mainly used as a substrate for the following methane fermentation processes [95]. In methane fermentation, $70 \%$ of the acetic acid is converted to methane and $10 \%$ to hydrogen. It has thus been reported that goat rumen fluid is an effective addition to the fermenter [96]. For example, research is being conducted on the production of biodiesel and bioethanol from noodle scraps using Saccharomyces cerevisiae K35 [97]. Other studies include the production of butanol using the Clostridiaceae family of bacteria and the production of methane and hydrogen mixtures from carbohydrate-rich food waste using anaerobic activated sludge [98]. Additionally, hydroxybutyrate, a precursor for bioplastics, has been successfully produced from sugarcane with a high yield (70.89\%) and productivity $(0.312 \mathrm{~g} / \mathrm{L} / \mathrm{h})$ using Alcaligenes sp. NCIM 5085 and Bacillus megaterium SRKP-3. Biomass, such as food waste, can therefore be used as an energy source [99].

Biomass, such as food waste, is also promising for producing various substances and as animal feed because it contains fixed nitrogen in various forms, such as proteins and nucleic acids [100-106]. For example, food waste can be used as organic fertiliser by digesting it with anaerobic bacteria [11]. Food waste can also be used as a culture medium component for microalgae [11]. Among food waste sources, soybean residues contain high amount of proteins $(\sim 31 \%)$, making them a promising raw material for ammonia production derived from food waste $[100,102,103]$. Furthermore, more than 3.9 million tonnes of soybean residue (okara) are generated annually worldwide as a byproduct of soy milk and tofu production, and more than $40 \%$ of it is landfilled or incinerated [100,101]. Additionally, most of the landfilled soybean residue is converted into nitrogen dioxide, a greenhouse gas, by microorganisms in the soil [31,107-109]. Recently, research on the use of okara as a food has been reported. For example, when okara treated with Eurotium cristatum, a type of fungus used in the production of Chinese tea, was mixed in the diet at a ratio of $20 \%$ and fed to type 2 diabetic mice, the high blood glucose levels were reduced to levels that allowed normal eating. This diet is sufficient in calories (348 kcal), well-balanced in dietary fibre $(5.5 \mathrm{~g} / 100 \mathrm{~g})$ and protein $(6.6 \mathrm{~g} / 100 \mathrm{~g})$, and low in fat $(2.5 \mathrm{~g} / 100 \mathrm{~g})$ [110]. Additionally, the fermentation of okara by the Lactobacillus acidophilus, Lacticaseibacillus rhamnosus, and Pediococcus acidilactici species gives it a buttery taste and enhances its value as a food. It has therefore been successfully used to add a buttery taste and increase its value as a food product [111].

Several attempts to produce ammonia from organic molecules containing nitrogen have been made (Table 1) [100,102-106]. For example, there is a study using Bacillus subtilis [102]. In this study, the codY gene was knocked out, after which the gene served as a transcriptional regulator of other genes, such as those involved in the branched-chain amino acid production and uptake. Next, $b k d B$ was also knocked out, and the gene, being a lipoamide acyltransferase, prevented the conversion of two-keto acids, which are sources of biofuels, to acyl CoA. Furthermore, the overexpression of the alcohol dehydrogenase leuDH gene promoted ammonia production. As a result, the production of biofuel, including the production of ammonia by deamination from amino acid-containing medium, was achieved with a theoretical yield of $46.6 \%$ [102]. Another attempt has been made to produce ammonia from amino acids using E. coli [112]. Since E. coli is a strong assimilator of ammonia, knockout of genes involved in ammonia assimilation was attempted. Moreover, knocking out the glutamine assimilation gene, $g \ln A$, was expected to increase the extracellular leaching of ammonia. Furthermore, the decarboxylase gene kivD was overex- 
pressed to unbalance the equilibrium reaction between ammonia production and amino acid production toward ammonia production. As a result, ammonia was produced from the amino acid-containing medium with a theoretical yield of $47.8 \%$ [112]. However, the above two studies were mainly experiments using amino acid-containing medium, and actual food waste was not used. Oriented toward the use of actual food waste, ammonia production from six media and four types of food waste was investigated using E. coli [106]. Furthermore, the correlation between the concentration of substances, such as amino acids, sugars, and organic acids, in the media and ammonia production was analysed by metabolic profiling, and it was found that glucose should inhibit ammonia production. Thus, when glucose was added to the M9 yeast extract medium at various concentrations, a negative correlation with ammonia production was observed. Therefore, by knocking out the glucose transporter $p t s G$ and deleting phosphoenolpyruvate, the phosphotransferase system, which transports major sugars such as glucose in E. coli, and the strain succeeded to produce ammonia of about $73 \%$ yield from sugar-containing amino acid medium. Additionally, ammonia production from pretreated soybean residues also succeeded for the first time with a conversion efficiency of about $47 \%$ and a high concentration of about $35 \mathrm{mM}$ (Figure 2b) [106]. In these studies, ammonia was produced intracellularly, which led to a tradeoff between microbial growth and ammonia production. Furthermore, in the study using Bacillus subtilis modified for ammonia biosynthesis, ammonia production plateaued on day 6 and did not increase on day 7 [102]. These results meant that the ammonia produced was used for cell growth. As one strategy for balancing production and growth, the approach of producing ammonia extracellularly is promising.

Table 1. Ammonia production from amino acids or food wastes by microorganisms.

\begin{tabular}{cccc}
\hline Microorganisms & Methods & Resource & References \\
\hline Bacillus subtilis & Metabolic engineering & $\begin{array}{c}\text { Amino acids-based } \\
\text { medium } \\
\text { Amino acids-based } \\
\text { medium } \\
\text { Escherichia coli }\end{array}$ & Metabolic engineering \\
Saccharomyces cerevisiae & Cell surface engineering & $\begin{array}{c}\text { Alutamine solution and } \\
\text { soybean residue } \\
\text { medium and soybean } \\
\text { residue }\end{array}$ & {$[112]$} \\
Saccharomyces cerevisiae & Cell surface engineering & $\begin{array}{c}\text { Amino acids solution and } \\
\text { soybean residue }\end{array}$ & {$[104]$} \\
\hline
\end{tabular}

Several attempts have been made to produce ammonia extracellularly. In some studies, yeast cell surface engineering systems have been used to avoid intracellular ammonia assimilation and toxicity $[105,113,114]$. In yeast cell surface engineering, for example, a secretory signal is added to the $\mathrm{N}$-terminus of a target protein, and an $\alpha$-agglutinin cell wall anchor protein containing a glycosylphosphatidylinositol anchor attachment signal sequence is added to the $\mathrm{C}$-terminus, thereby allowing the target protein to be displayed on the cell surface $[105,113-115]$. About $10^{5}-10^{6}$ target proteins can be presented on the cell surface, and yeast cells can be used as biocatalysts for enzyme immobilisation $[105,113,114]$. Furthermore, proteins immobilised on the cell surface are known to be stabilised, and in some cases show higher enzyme activity than in the free state. Additionally, since the eukaryotic folding machinery was retained, various proteins can be displayed [115]. Therefore, due to these advantages, yeast cell surface engineering has been successfully used to produce ethanol from carbohydrates, woody biomass, and macroalgae with high efficiency [116-118]. Furthermore, ammonia production from soybean residues has been attempted using yeast cell surface engineering [104]. Deaminase, transaminase, oxidase, and ammonia-lyase are known as amino acid catabolic enzymes that can produce ammonia from amino acids. Unlike nitrogenases, these proteins can produce ammonia from amino acids with a single enzyme. Ammonia lyases are particularly suitable for display on the sur- 
face of yeast cells because they do not require cofactors for catalysis. In a study using yeast displaying glutamine ammonia-lyase $\mathrm{YbaS}$, ammonia production from a glutamine solution succeeded with high efficiency (83.2\%) and concentration (3.34 g/L) [104]. Additionally, although it is known that ammonia at concentrations higher than $0.1 \%(v / v)$ inhibited the growth of yeast, any impairment of the microbial catalyst was not observed due to ammonia toxicity in this approach [104,119]. YbaS-presenting yeast also succeeded in producing ammonia with high efficiency from pretreated okara solution, which is thought to contain various substances that inhibit ammonia production. The problem with ammonia production using YbaS ammonia-lyase was that it only used glutamine among the 20 amino acids derived from proteins [120]. Additionally, L-amino acid oxidase has broad substrate specificity and can produce ammonia from various amino acids [105,121,122]. For example, L-amino acid oxidase from Aplysia californica is active against L-arginine and L-lysine [123,124]. Additionally, the L-amino acid oxidase contained in the venom of venomous snakes, such as Bothrops atrox, Crotalus viridis helleri, and Daboia russelii, has been well studied and is inactive against amino acids, such as L-glutamine and L-aspartate; however, it is active against hydrophobic amino acids, such as L-leucine, hydrophilic amino acids, such as L-histidine and L-methionine, and aromatic amino acids, such as L-tyrosine and L-phenylalanine [120,122,125]. Further, since Hebeloma cylindrosporum has mycelium for the intracellular absorption of ammonia from free amino acids dissolved in the soil, it is expected to have enzymes with wide specificity. In literature, enzymes that can produce ammonia from more than 10 amino acids are known [126]. Therefore, if L-amino acid oxidase (HcLAAO) from H. cylindrosporum can be constructed to express in a budding yeast, more efficient ammonia production from food waste was expected. HcLAAO, which has been successfully expressed in budding yeast, and is highly efficient for ammonia production (about $88 \%$ ), have been achieved under mild conditions $\left(30^{\circ} \mathrm{C}\right)$ from pretreated okara solutions (Figure 2c) [105]. In this study, as in the previous study of glutamine ammonia-lyase, no toxic effects of extracellular ammonia were observed. Thus, attempts have been successfully made to produce ammonia from food waste, but these studies are all lab-scale studies. In the future, it is expected that field tests on an industrial scale will be studied for social implementation. Additionally, the use of metabolically optimised and cell-engineered microorganisms to produce ammonia, instead of the Haber-Bosch process, would be a promising and environmentally friendly approach to solve the global ammonia demand problem and develop a sustainable carbon-free society.

\section{Conclusions}

In this review, we presented various efforts to achieve sustainable microbial ammonia production. These studies have provided important insights for achieving a carbon-free society [126].

However, many issues should be solved in the future to implement ammonia production using these biological methods in society. For example, it is still difficult to use the nitrogenase complex in vitro, as it is necessary to provide it with high stability and oxygen tolerance. Additionally, although attempts for the heterologous expression of nitrogenase complexes in plant cells still face problems, such as the fact that about half of the subunits are insoluble, many methods to increase the solubility of proteins have been developed in the field of protein engineering, and it will be possible to overcome this problem by applying these techniques in the future. As an approach to use nitrogen-fixing bacteria with nitrogenase for agricultural production, PROVEN, invented by Pivot Bio, Inc., using nitrogen-fixing bacteria has been successful. It is expected to support carbon-free food production without relying on chemical fertilisers in the future. Additionally, various studies have been conducted on the effective use of food waste, which has recently been increasing. Therefore, the production of ammonia from food waste can be achieved using budding yeast with amino acid catabolic enzymes immobilised outside the cells. In the future, research on an industrial scale for social implementation is expected. 
Author Contributions: Conceptualization, Y.W.; writing-original draft preparation, Y.W.; writingreview and editing, Y.W. and W.A.; supervision, M.U.; funding acquisition, W.A. and M.U. All authors have read and agreed to the published version of the manuscript.

Funding: JST CREST (grant number JPMJCR16G2), JST COI-NEXT (grant number JPMJPF2008) and JST FOREST (grant number JPMJFR204K), Japan for funded.

Institutional Review Board Statement: Not applicable.

Informed Consent Statement: Not applicable.

Acknowledgments: This study was supported by JST CREST (grant number JPMJCR16G2 to M.U.), JST COI-NEXT (grant number JPMJPF2008 to M.U.) and JST FOREST (grant number JPMJFR204K to W.A.).

Conflicts of Interest: The authors declare no conflict of interest.

\section{References}

1. Tortell, P.D. Earth 2020: Science, society, and sustainability in the Anthropocene. Proc. Natl. Acad. Sci. USA 2020, 117, 8683-8691. [CrossRef] [PubMed]

2. Capua, I.; Giovannini, E. Coding system to track research progress towards SDGs. Nature 2019, 572, 178. [CrossRef]

3. Demirhan, C.D.; Tso, W.W.; Powell, J.B.; Pistikopoulos, E.N. Sustainable ammonia production through process synthesis and global optimization. Aiche J. 2019, 65, e16498. [CrossRef]

4. Mitsos, A.; Asprion, N.; Floudas, C.A.; Bortz, M.; Baldea, M.; Bonvin, D.; Caspari, A.; Schafer, P. Challenges in process optimization for new feedstocks and energy sources. Comput. Chem. Eng. 2018, 113, 209-221. [CrossRef]

5. Wang, L.; Xia, M.K.; Wang, H.; Huang, K.F.; Qian, C.X.; Maravelias, C.T.; Ozin, G.A. Greening Ammonia toward the Solar Ammonia Refinery. Joule 2018, 2, 1055-1074. [CrossRef]

6. Valera-Medina, A.; Amer-Hatem, F.; Azad, A.K.; Dedoussi, I.C.; de Joannon, M.; Fernandes, R.X.; Glarborg, P.; Hashemi, H.; He, X.; Mashruk, S.; et al. Review on Ammonia as a Potential Fuel: From Synthesis to Economics. Energy Fuel 2021, 35, 6964-7029. [CrossRef]

7. Graziano, M.; Lecca, P.; Musso, M. Historic paths and future expectations: The macroeconomic impacts of the offshore wind technologies in the UK. Energy Policy 2017, 108, 715-730. [CrossRef]

8. Elishav, O.; Mosevitzky Lis, B.; Miller, E.M.; Arent, D.J.; Valera-Medina, A.; Grinberg Dana, A.; Shter, G.E.; Grader, G.S. Progress and Prospective of Nitrogen-Based Alternative Fuels. Chem. Rev. 2020, 120, 5352-5436. [PubMed]

9. Baliban, R.C.; Elia, J.A.; Floudas, C.A. Biomass and Natural Gas to Liquid Transportation Fuels: Process Synthesis, Global Optimization, and Topology Analysis. Ind. Eng. Chem. Res. 2013, 52, 3381-3406. [CrossRef]

10. Lynd, L.R.; Larson, E.; Greene, N.; Laser, M.; Sheehan, J.; Dale, B.E.; McLaughlin, S.; Wang, M. The role of biomass in America's energy future: Framing the analysis. Biofuels Bioprod. Biorefin. 2009, 3, 113-123. [CrossRef]

11. Paritosh, K.; Kushwaha, S.K.; Yadav, M.; Pareek, N.; Chawade, A.; Vivekanand, V. Food Waste to Energy: An Overview of Sustainable Approaches for Food Waste Management and Nutrient Recycling. BioMed Res. Int. 2017. [CrossRef] [PubMed]

12. Erdemir, D.; Dincer, I. A perspective on the use of ammonia as a clean fuel: Challenges and solutions. Int. J. Energy Res. 2021, 45, 4827-4834. [CrossRef]

13. Fedoruk, M.J.; Bronstein, R.; Kerger, B.D. Ammonia exposure and hazard assessment for selected household cleaning product uses. J. Expo. Sci. Environ. Epidemiol. 2005, 15, 534-544. [CrossRef]

14. Hu, B.; Huang, S.M.; Shao, Y.Y.; Chen, J.C. Thermodynamic analysis of a new ammonia-water power cycle. Energy Rep. 2020, 6, 567-573. [CrossRef]

15. Wakida, T.; Tokuyama, T.; Doi, C.; Lee, M.; Jeong, D.S.; Ishida, S. Mechanical properties of polyester/cotton and polyester/rayon fabrics treated with ammonia-gas. Sen-I Gakkaishi 2004, 60, 34-37. [CrossRef]

16. Muller, T.E.; Beller, M. Metal-Initiated Amination of Alkenes and Alkynes. Chem. Rev. 1998, 98, 675-704. [CrossRef] [PubMed]

17. Park, S.; Jeong, J.; Fujita, K.I.; Yamamoto, A.; Yoshida, H. Anti-Markovnikov Hydroamination of Alkenes with Aqueous Ammonia by Metal-Loaded Titanium Oxide Photocatalyst. J. Am. Chem. Soc. 2020, 142, 12708-12714. [CrossRef] [PubMed]

18. Miura, D.; Tezuka, T. A comparative study of ammonia energy systems as a future energy carrier, with particular reference to vehicle use in Japan. Energy 2014, 68, 428-436. [CrossRef]

19. Green, L. An Ammonia Energy Vector for the Hydrogen Economy. Int. J. Hydrogen Energy 1982, 7, 355-359. [CrossRef]

20. Mukherjee, P.; Rao, V.V. Design and development of high temperature superconducting magnetic energy storage for power applications-A review. Physics C 2019, 563, 67-73. [CrossRef]

21. Rehman, S.; Al-Hadhrami, L.M.; Alam, M.M. Pumped hydro energy storage system: A technological review. Renew. Sustain. Energy Rev. 2015, 44, 586-598. [CrossRef]

22. Gur, T.M. Review of electrical energy storage technologies, materials and systems: Challenges and prospects for large-scale grid storage. Energy Environ. Sci. 2018, 11, 3055. [CrossRef]

23. Al Shaqsi, A.Z.; Sopian, K.; Al-Hinai, A. Review of energy storage services, applications, limitations, and benefits. Energy Rep. 2020, 6, 288-306. [CrossRef] 
24. Djinović, P.S. Electrochemical Energy Storage for Renewable Sources and Grid Balancing; Elsevier: Amsterdam, The Netherlands, 2015; pp. 183-199.

25. Lan, R.; Irvine, J.T.S.; Tao, S.W. Ammonia and related chemicals as potential indirect hydrogen storage materials. Int. J. Hydrogen Energy 2012, 37, 1482-1494. [CrossRef]

26. Wang, W.T.; Herreros, J.M.; Tsolakis, A.; York, A.P.E. Ammonia as hydrogen carrier for transportation; investigation of the ammonia exhaust gas fuel reforming. Int. J. Hydrogen Energy 2013, 38, 9907-9917. [CrossRef]

27. Kishimoto, M.; Muroyama, H.; Suzuki, S.; Saito, M.; Koide, T.; Takahashi, Y.; Horiuchi, T.; Yamasaki, H.; Matsumoto, S.; Kubo, H.; et al. Development of $1 \mathrm{~kW}$-class Ammonia-fueled Solid Oxide Fuel Cell Stack. Fuel Cells 2020, 20, 80-88. [CrossRef]

28. Zhao, Y.; Setzler, B.P.; Wang, J.H.; Nash, J.; Wang, T.; Xu, B.J.; Yan, Y.S. An Efficient Direct Ammonia Fuel Cell for Affordable Carbon-Neutral Transportation. Joule 2019, 3, 2472-2484. [CrossRef]

29. Schrock, R.R. Reduction of dinitrogen. Proc. Natl. Acad. Sci. USA 2006, 103, 17087. [CrossRef]

30. Erisman, J.W.; Sutton, M.A.; Galloway, J.; Klimont, Z.; Winiwarter, W. How a century of ammonia synthesis changed the world. Nat. Geosci. 2008, 1, 636-639. [CrossRef]

31. Canfield, D.E.; Glazer, A.N.; Falkowski, P.G. The Evolution and Future of Earth's Nitrogen Cycle. Science 2010, 330, 192-196. [CrossRef]

32. Smil, V. Population-Growth and Nitrogen-An Exploration of a Critical Existential Link. Popul. Dev. Rev. 1991, 17, 569-601. [CrossRef]

33. John Humphreys, R.L.; Tao, S. Development and Recent Progress on Ammonia Synthesis Catalysts for Haber-Bosch Process. Adv. Energy Sustain. Res. 2020, 2, 1-23.

34. Ashida, Y.; Arashiba, K.; Tanaka, H.; Egi, A.; Nakajima, K.; Yoshizawa, K.; Nishibayashi, Y. Molybdenum-Catalyzed Ammonia Formation Using Simple Monodentate and Bidentate Phosphines as Auxiliary Ligands. Inorg. Chem. 2019, 58, 8927-8932. [CrossRef] [PubMed]

35. Buscagan, T.M.; Rees, D.C. Rethinking the Nitrogenase Mechanism: Activating the Active Site. Joule 2019, 3, 2662-2678. [CrossRef]

36. Ashida, Y.; Arashiba, K.; Nakajima, K.; Nishibayashi, Y. Molybdenum-catalysed ammonia production with samarium diiodide and alcohols or water. Nature 2019, 568, 536-540. [CrossRef]

37. Reid, W.V.; Ali, M.K.; Field, C.B. The future of bioenergy. Glob. Chang. Biol. 2020, 26, 274-286. [CrossRef]

38. Akhlaghi, N.; Najafpour-Darzi, G. A comprehensive review on biological hydrogen production. Int. J. Hydrogen Energy 2020, 45, 22492-22512. [CrossRef]

39. Mohamad, N.L.; Kamal, S.M.M.; Mokhtar, M.N. Xylitol Biological Production: A Review of Recent Studies. Food Rev. Int. 2015, 31, 74-89. [CrossRef]

40. Ma, H.Z.; Wang, Q.H.; Qian, D.Y.; Gong, L.J.; Zhang, W.Y. The utilization of acid-tolerant bacteria on ethanol Production from kitchen garbage. Renew. Energy 2009, 34, 1466-1470. [CrossRef]

41. Mahidhara, G.; Burrow, H.; Sasikala, C.; Ramana, C.V. Biological hydrogen production: Molecular and electrolytic perspectives. World J. Microbiol. Biotechnol. 2019, 35, 8. [CrossRef] [PubMed]

42. Rittmann, S.; Herwig, C. A comprehensive and quantitative review of dark fermentative biohydrogen production. Microbiol. Cell Fact. 2012, 11, 115. [CrossRef] [PubMed]

43. Costa, F.; Lago, A.; Rocha, V.; Barros, O.; Costa, L.; Vipotnik, Z.; Silva, B.; Tavares, T. A Review on Biological Processes for Pharmaceuticals Wastes Abatement-A Growing Threat to Modern Society. Environ. Sci. Technol. 2019, 53, 7185-7202. [CrossRef] [PubMed]

44. Lopes, M.S.G. Engineering biological systems toward a sustainable bioeconomy. J. Ind. Microbiol. Biotechnol. 2015, 42, 813-838. [CrossRef] [PubMed]

45. Schmid, A.; Dordick, J.S.; Hauer, B.; Kiener, A.; Wubbolts, M.; Witholt, B. Industrial biocatalysis today and tomorrow. Nature 2001, 409, 258-268. [CrossRef]

46. Thomas, S.M.; DiCosimo, R.; Nagarajan, A. Biocatalysis: Applications and potentials for the chemical industry. Trends Biotechnol. 2002, 20, 444. [CrossRef]

47. Ogawa, J.; Shimizu, S. Microbial enzymes: New industrial applications from traditional screening methods. Trends Biotechnol. 1999, 17, 13-21. [CrossRef]

48. Pettersen, E.F.; Goddard, T.D.; Huang, C.C.; Couch, G.S.; Greenblatt, D.M.; Meng, E.C.; Ferrin, T.E. UCSF Chimera-A visualization system for exploratory research and analysis. J. Comput. Chem. 2004, 25, 1605-1612. [CrossRef]

49. Schindelin, N.; Kisker, C.; Sehlessman, J.L.; Howard, J.B.; Rees, D.C. Structure of ADP center dot AIF(4)(-)-stabilized nitrogenase complex and its implications for signal transduction. Nature 1997, 387, 370-376. [CrossRef]

50. Rapson, T.D.; Gregg, C.M.; Allen, R.S.; Ju, H.; Doherty, C.M.; Mulet, X.; Giddey, S.; Wood, C.C. Insights into Nitrogenase Bioelectrocatalysis for Green Ammonia Production. Chemsuschem 2020, 13, 4856-4865. [CrossRef] [PubMed]

51. Lindstrom, K.; Mousavi, S.A. Effectiveness of nitrogen fixation in rhizobia. Microbiol. Biotechnol. 2020, 13, 1314-1335. [CrossRef]

52. Philippot, L.; Raaijmakers, J.M.; Lemanceau, P.; van der Putten, W.H. Going back to the roots: The microbial ecology of the rhizosphere. Nat. Rev. Microbiol. 2013, 11, 789-799. [CrossRef] [PubMed]

53. Gruber, N.; Galloway, J.N. An Earth-system perspective of the global nitrogen cycle. Nature 2008, 451, 293-296. [CrossRef]

54. Field, C.B.; Behrenfeld, M.J.; Randerson, J.T.; Falkowski, P. Primary production of the biosphere: Integrating terrestrial and oceanic components. Science 1998, 281, 237-240. [CrossRef]

55. Snider, M.G.; Temple, B.S.; Wolfenden, R. The path to the transition state in enzyme reactions: A survey of catalytic efficiencies. J. Phys. Org. Chem. 2004, 17, 586-591. [CrossRef] 
56. Garcia, H.G.; Tikhonov, M.; Lin, A.; Gregor, T. Quantitative imaging of transcription in living Drosophila embryos links polymerase activity to patterning. Curr. Biol. CB 2013, 23, 2140-2145. [CrossRef]

57. Ingolia, N.T.; Lareau, L.F.; Weissman, J.S. Ribosome profiling of mouse embryonic stem cells reveals the complexity and dynamics of mammalian proteomes. Cell 2011, 147, 789-802. [CrossRef]

58. Einsle, O.; Rees, D.C. Structural Enzymology of Nitrogenase Enzymes. Chem. Rev. 2020, 120, 4969-5004. [CrossRef]

59. Cai, R.; Minteer, S.D. Nitrogenase Bioelectrocatalysis: From Understanding Electron-Transfer Mechanisms to Energy Applications. ACS Energy Lett. 2018, 3, 2736-2742. [CrossRef]

60. Milton, R.D.; Minteer, S.D. Nitrogenase Bioelectrochemistry for Synthesis Applications. Acc. Chem. Res. 2019, 52, 3351-3360. [CrossRef]

61. Peters, J.W.; Szilagyi, R.K. Exploring new frontiers of nitrogenase structure and mechanism. Curr. Opin. Chem. Biol. 2006, 10, 101-108. [CrossRef]

62. Hoffman, B.M.; Lukoyanov, D.; Yang, Z.Y.; Dean, D.R.; Seefeldt, L.C. Mechanism of nitrogen fixation by nitrogenase: The next stage. Chem. Rev. 2014, 114, 4041-4062. [CrossRef] [PubMed]

63. Eady, R.R. Structure-function relationships of alternative nitrogenases. Chem. Rev. 1996, 96, 3013-3030. [CrossRef] [PubMed]

64. Weininger, M.S.; Mortenson, L.E. Crystallographic Properties of the Mofe Proteins of Nitrogenase from Clostridium-Pasteurianum and Azotobacter-Vinelandii. Proc. Natl. Acad. Sci. USA 1982, 79, 378-380. [CrossRef] [PubMed]

65. Einsle, O.; Tezcan, F.A.; Andrade, S.L.A.; Schmid, B.; Yoshida, M.; Howard, J.B.; Rees, D.C. Nitrogenase MoFe-protein at 1.16 angstrom resolution: A central ligand in the FeMo-cofactor. Science 2002, 297, 1696-1700. [CrossRef] [PubMed]

66. Yang, J.G.; Xie, X.Q.; Xiang, N.; Tian, Z.X.; Dixon, R.; Wang, P. Polyprotein strategy for stoichiometric assembly of nitrogen fixation components for synthetic biology. Proc. Natl. Acad. Sci. USA 2018, 115, E8509-E8517. [CrossRef]

67. Wang, L.Y.; Zhang, L.H.; Liu, Z.Z.; Zhao, D.H.; Liu, X.M.; Zhang, B.; Xie, J.B.; Hong, Y.Y.; Li, P.F.; Chen, S.F.; et al. A Minimal Nitrogen Fixation Gene Cluster from Paenibacillus sp WLY78 Enables Expression of Active Nitrogenase in Escherichia coli. PLoS Genet. 2013, 9, e1003865. [CrossRef]

68. Li, X.X.; Liu, Q.; Liu, X.M.; Shi, H.W.; Chen, S.F. Using synthetic biology to increase nitrogenase activity. Microbiol. Cell Fact. 2016, 15, 43. [CrossRef]

69. Yang, J.; Xie, X.; Wang, X.; Dixon, R.; Wang, Y.P. Reconstruction and minimal gene requirements for the alternative iron-only nitrogenase in Escherichia coli. Proc. Natl. Acad. Sci. USA 2014, 111, E3718-E3725. [CrossRef]

70. Lopez-Torrejon, G.; Jimenez-Vicente, E.; Buesa, J.M.; Hernandez, J.A.; Verma, H.K.; Rubio, L.M. Expression of a functional oxygenlabile nitrogenase component in the mitochondrial matrix of aerobically grown yeast. Nat. Commun. 2016, 7, 11426. [CrossRef]

71. Lopez-Torrejon, G.; Buren, S.; Veldhuizen, M.; Rubio, L.M. Biosynthesis of cofactor-activatable iron-only nitrogenase in Saccharomyces cerevisiae. Microbiol. Biotechnol. 2021, 14, 1073-1083. [CrossRef]

72. Buren, S.; Jiang, X.; Lopez-Torrejon, G.; Echavarri-Erasun, C.; Rubio, L.M. Purification and In Vitro Activity of Mitochondria Targeted Nitrogenase Cofactor Maturase NifB. Front. Plant. Sci. 2017, 8, 1567. [CrossRef] [PubMed]

73. Buren, S.; Pratt, K.; Jiang, X.; Guo, Y.; Jimenez-Vicente, E.; Echavarri-Erasun, C.; Dean, D.R.; Saaem, I.; Gordon, D.B.; Voigt, C.A.; et al. Biosynthesis of the nitrogenase active-site cofactor precursor NifB-co in Saccharomyces cerevisiae. Proc. Natl. Acad. Sci. USA 2019, 116, 25078-25086. [CrossRef] [PubMed]

74. Okada, S.; Gregg, C.M.; Allen, R.S.; Menon, A.; Hussain, D.; Gillespie, V.; Johnston, E.; Byrne, K.; Colgrave, M.L.; Wood, C.C. A Synthetic Biology Workflow Reveals Variation in Processing and Solubility of Nitrogenase Proteins Targeted to Plant Mitochondria, and Differing Tolerance of Targeting Sequences in a Bacterial Nitrogenase Assay. Front. Plant. Sci. 2020, 11, 552160. [CrossRef] [PubMed]

75. Xiang, N.; Guo, C.Y.; Liu, J.W.; Xu, H.; Dixon, R.; Yang, J.G.; Wang, Y.P. Using synthetic biology to overcome barriers to stable expression of nitrogenase in eukaryotic organelles. Proc. Natl. Acad. Sci. USA 2020, 117, 24602. [CrossRef] [PubMed]

76. Allen, R.S.; Gregg, C.M.; Okada, S.; Menon, A.; Hussain, D.; Gillespie, V.; Johnston, E.; Devilla, R.; Warden, A.C.; Taylor, M.; et al. Plant expression of NifD protein variants resistant to mitochondrial degradation. Proc. Natl. Acad. Sci. USA 2020, 117, 23165-23173. [CrossRef]

77. Chretien, D.; Benit, P.; Ha, H.H.; Keipert, S.; El-Khoury, R.; Chang, Y.T.; Jastroch, M.; Jacobs, H.T.; Rustin, P.; Rak, M. Mitochondria are physiologically maintained at close to 50 degrees C. PLoS Biol. 2018, 16, e2003992. [CrossRef]

78. Li, Q.; Chen, S. Transfer of Nitrogen Fixation (nif) Genes to Non-diazotrophic Hosts. Chembiochem 2020, 21, 1717-1722. [CrossRef]

79. Dong, F.; Lee, Y.S.; Gaffney, E.M.; Grattieri, M.; Haddadin, H.; Minteer, S.D.; Chen, H. An engineered, non-diazotrophic cyanobacterium and its application in bioelectrochemical nitrogen fixation. Cell Rep. Phys. Sci. 2021, 2, 100444. [CrossRef]

80. Mehta, M.P.; Baross, J.A. Nitrogen fixation at 92 degrees $C$ by a hydrothermal vent archaeon. Science 2006, 314, 1783-1786. [CrossRef]

81. DiCosimo, R.; McAuliffe, J.; Poulose, A.J.; Bohlmann, G. Industrial use of immobilized enzymes. Chem. Soc. Rev. 2013, 42, 6437-6474. [CrossRef] [PubMed]

82. Patel, J.; Cai, R.; Milton, R.; Chen, H.; Minteer, S.D. Pyrene-Based Noncovalent Immobilization of Nitrogenase on Carbon Surfaces Chembiochem 2020, 21, 1729-1732. [CrossRef] [PubMed]

83. Schlesier, J.; Rohde, M.; Gerhardt, S.; Einsle, O. A Conformational Switch Triggers Nitrogenase Protection from Oxygen Damage by Shethna Protein II (FeSII). J. Am. Chem. Soc. 2016, 138, 239-247. [CrossRef] [PubMed]

84. Yang, J.; Xie, X.; Yang, M.; Dixon, R.; Wang, Y.P. Modular electron-transport chains from eukaryotic organelles function to support nitrogenase activity. Proc. Natl. Acad. Sci. USA 2017, 114, E2460-E2465. [CrossRef] [PubMed] 
85. Wheatley, R.M.; Ford, B.L.; Li, L.; Aroney, S.T.N.; Knights, H.E.; Ledermann, R.; East, A.K.; Ramachandran, V.K.; Poole, P.S. Lifestyle adaptations of Rhizobium from rhizosphere to symbiosis. Proc. Natl. Acad. Sci. USA 2020, 117, 23823-23834. [CrossRef] [PubMed]

86. Wang, L.L.; Rubio, M.C.; Xin, X.; Zhang, B.L.; Fan, Q.L.; Wang, Q.; Ning, G.G.; Becana, M.; Duanmu, D.Q. CRISPR/Cas9 knockout of leghemoglobin genes in Lotus japonicus uncovers their synergistic roles in symbiotic nitrogen fixation. New Phytol. 2019, 224, 818-832. [CrossRef]

87. Nonaka, A.; Yamamoto, H.; Kamiya, N.; Kotani, H.; Yamakawa, H.; Tsujimoto, R.; Fujita, Y. Accessory Proteins of the Nitrogenase Assembly, NifW, NifX/NafY, and NifZ, Are Essential for Diazotrophic Growth in the Nonheterocystous Cyanobacterium Leptolyngbya boryana. Front. Microbiol. 2019, 10, 495. [CrossRef]

88. Karsten, T.; Alvin, T.; Sarah, B.; Rosemary, C.; Emily, T.; Kevin, H.; Douglas, H.; Austin, D. Methods and Compositions for Improving Plant. Traits. Patent WO2017011602A1, 19 January 2017.

89. Pivot Bio. Pivot Bio 2020 Performance Report; Pivot Bio: Berkeley, CA, USA, 2021.

90. FAO. Towards the Future we Want: End Hunger and Make the Transition to Sustainable Agricultural and Food Systems; FAO: Rome, Italy, 2012.

91. Melikoglu, M.; Lin, C.S.K.; Webb, C. Analysing global food waste problem: Pinpointing the facts and estimating the energy content. Open Eng. 2013, 3, 157-164. [CrossRef]

92. Van Dyk, J.S.; Gama, R.; Morrison, D.; Swart, S.; Pletschke, B.I. Food processing waste: Problems, current management and prospects for utilisation of the lignocellulose component through enzyme synergistic degradation. Renew. Sustain. Energy Rev. 2013, 26, 521-531. [CrossRef]

93. Nasir, I.M.; Ghazi, T.I.M.; Omar, R. Production of biogas from solid organic wastes through anaerobic digestion: A review. Appl. Microbiol. Biotechnol. 2012, 95, 321-329. [CrossRef]

94. Morita, M.; Sasaki, K. Factors influencing the degradation of garbage in methanogenic bioreactors and impacts on biogas formation. Appl. Microbiol. Biotechnol. 2012, 94, 575-582. [CrossRef]

95. Schink, B. Energetics of syntrophic cooperation in methanogenic degradation. Microbiol. Mol. Biol. Rev. 1997, 61, 262-280. [CrossRef]

96. Griffin, M.E.; McMahon, K.D.; Mackie, R.I.; Raskin, L. Methanogenic population dynamics during start-up of anaerobic digesters treating municipal solid waste and biosolids. Biotechnol. Bioeng. 1998, 57, 342-355. [CrossRef]

97. Yang, X.; Lee, S.J.; Yoo, H.Y.; Choi, H.S.; Park, C.; Kim, S.W. Biorefinery of instant noodle waste to biofuels. Bioresour. Technol. 2014, 159, 17-23. [CrossRef] [PubMed]

98. Si, B.C.; Li, J.M.; Zhu, Z.B.; Zhang, Y.H.; Lu, J.W.; Shen, R.X.; Zhang, C.; Xing, X.H.; Liu, Z. Continuous production of biohythane from hydrothermal liquefied cornstalk biomass via two-stage high-rate anaerobic reactors. Biotechnol. Biofuels $2016,9,254$. [CrossRef] [PubMed]

99. Tripathi, A.D.; Joshi, T.R.; Srivastava, S.K.; Darani, K.K.; Khade, S.; Srivastava, J. Effect of nutritional supplements on bio-plastics (PHB) production utilizing sugar refinery waste with potential application in food packaging. Prep. Biochem. Biotechnol. 2019, 49, 567-577. [CrossRef]

100. Vong, W.C.; Au Yang, K.L.C.; Liu, S.Q. Okara (soybean residue) biotransformation by yeast Yarrowia lipolytica. Int. J. Food Microbiol. 2016, 235, 1-9. [CrossRef]

101. Liu, C.; Hotta, Y.; Santo, A.; Hengesbaugh, M.; Watabe, A.; Totoki, Y.; Allen, D.; Bengtsson, M. Food waste in Japan: Trends, current practices and key challenges. J. Clean Prod. 2016, 133, 557-564. [CrossRef]

102. Choi, K.Y.; Wernick, D.G.; Tat, C.A.; Liao, J.C. Consolidated conversion of protein waste into biofuels and ammonia using Bacillus subtilis. Metab. Eng. 2014, 23, 53-61. [CrossRef]

103. Huo, Y.X.; Cho, K.M.; Rivera, J.G.L.; Monte, E.; Shen, C.R.; Yan, Y.J.; Liao, J.C. Conversion of proteins into biofuels by engineering nitrogen flux. Nat. Biotechnol. 2011, 29, 346-U160. [CrossRef]

104. Watanabe, Y.; Kuroda, K.; Tatemichi, Y.; Nakahara, T.; Aoki, W.; Ueda, M. Construction of engineered yeast producing ammonia from glutamine and soybean residues (okara). AMB Express 2020, 10, 70. [CrossRef]

105. Watanabe, Y.; Aoki, W.; Ueda, M. Improved ammonia production from soybean residues by cell surface-displayed L-amino acid oxidase on yeast. Biosci. Biotechnol. Biochem. 2021, 85, 972-980. [CrossRef] [PubMed]

106. Tatemichi, Y.; Kuroda, K.; Nakahara, T.; Ueda, M. Efficient ammonia production from food by-products by engineered Escherichia coli. AMB Express 2020, 10, 150. [CrossRef] [PubMed]

107. Katami, T.; Yasuhara, A.; Shibamoto, T. Formation of dioxins from incineration of foods found in domestic garbage. Environ. Sci. Technol. 2004, 38, 1062-1065. [CrossRef] [PubMed]

108. Galloway, J.N.; Townsend, A.R.; Erisman, J.W.; Bekunda, M.; Cai, Z.C.; Freney, J.R.; Martinelli, L.A.; Seitzinger, S.P.; Sutton, M.A. Transformation of the nitrogen cycle: Recent trends, questions, and potential solutions. Science 2008, 320, 889-892. [CrossRef]

109. Montzka, S.A.; Dlugokencky, E.J.; Butler, J.H. Non-CO2 greenhouse gases and climate change. Nature 2011, 476, 43-50. [CrossRef]

110. Chan, L.Y.; Takahashi, M.; Lim, P.J.; Aoyama, S.; Makino, S.; Ferdinandus, F.; Ng, S.C.; Arai, S.; Fujita, H.; Tan, H.C.; et al. Eurotium Cristatum Fermented Okara as a Potential Food Ingredient to Combat Diabetes. Sci. Rep. 2019, 9, 17536. [CrossRef]

111. Hadj Saadoun, J.; Calani, L.; Cirlini, M.; Bernini, V.; Neviani, E.; Del Rio, D.; Galaverna, G.; Lazzi, C. Effect of fermentation with single and co-culture of lactic acid bacteria on okara: Evaluation of bioactive compounds and volatile profiles. Food Funct. 2021, 12, 3033-3043. [CrossRef] [PubMed]

112. Mikami, Y.; Yoneda, H.; Tatsukami, Y.; Aoki, W.; Ueda, M. Ammonia production from amino acid-based biomass-like sources by engineered Escherichia coli. AMB Express 2017, 7, 83. [CrossRef] 
113. Ueda, M.; Tanaka, A. Cell surface engineering of yeast: Construction of arming yeast with biocatalyst. J. Biosci. Bioeng. 2000, 90, 125-136. [CrossRef]

114. Kuroda, K.; Ueda, M. Cell surface engineering of yeast for applications in white biotechnology. Biotechnol. Lett. 2011, 33, 1-9. [CrossRef]

115. Ueda, M. Establishment of cell surface engineering and its development. Biosci. Biotechnol. Biochem. 2016, 80, 1243-1253. [CrossRef]

116. Nakanishi, A.; Kuroda, K.; Ueda, M. Direct fermentation of newspaper after laccase-treatment using yeast codisplaying endoglucanase, cellobiohydrolase, and beta-glucosidase. Renew. Energy 2012, 44, 199-205. [CrossRef]

117. Takagi, T.; Yokoi, T.; Shibata, T.; Morisaka, H.; Kuroda, K.; Ueda, M. Engineered yeast whole-cell biocatalyst for direct degradation of alginate from macroalgae and production of non-commercialized useful monosaccharide from alginate. Appl. Microbiol. Biotechnol. 2016, 100, 1723-1732. [CrossRef]

118. Motone, K.; Takagi, T.; Sasaki, Y.; Kuroda, K.; Ueda, M. Direct ethanol fermentation of the algal storage polysaccharide laminarin with an optimized combination of engineered yeasts. J. Biotechnol. 2016, 231, 129-135. [CrossRef]

119. Santos, J.; Sousa, M.J.; Leao, C. Ammonium is toxic for aging yeast cells, inducing death and shortening of the chronological lifespan. PLoS ONE 2012, 7, e37090. [CrossRef]

120. Pollegioni, L.; Motta, P.; Molla, G. L-Amino acid oxidase as biocatalyst: A dream too far? Appl. Microbiol. Biotechnol. 2013, 97, 9323-9341. [CrossRef]

121. Lu, P.L.; Ma, D.; Chen, Y.L.; Guo, Y.Y.; Chen, G.Q.; Deng, H.T.; Shi, Y.G. L-glutamine provides acid resistance for Escherichia coli through enzymatic release of ammonia. Cell Res. 2013, 23, 635-644. [CrossRef]

122. Bloess, S.; Beuel, T.; Kruger, T.; Sewald, N.; Dierks, T.; Fischer von Mollard, G. Expression, characterization, and site-specific covalent immobilization of an L-amino acid oxidase from the fungus Hebeloma cylindrosporum. Appl. Microbiol. Biotechnol. 2019, 103, 2229-2241. [CrossRef] [PubMed]

123. Yang, H.; Johnson, P.M.; Ko, K.C.; Kamio, M.; Germann, M.W.; Derby, C.D.; Tai, P.C. Cloning, characterization and expression of escapin, a broadly antimicrobial FAD-containing L-amino acid oxidase from ink of the sea hare Aplysia californica. J. Exp. Biol. 2005, 208, 3609-3622. [CrossRef] [PubMed]

124. Ko, K.C.; Wang, B.; Tai, P.C.; Derby, C.D. Identification of potent bactericidal compounds produced by escapin, an L-amino acid oxidase in the ink of the sea hare Aplysia californica. Antimicrob. Agents Chemother. 2008, 52, 4455-4462. [CrossRef]

125. Ullah, A. Structure-Function Studies and Mechanism of Action of Snake Venom L-Amino Acid Oxidases. Front. Pharm. 2020, 11, 110. [CrossRef] [PubMed]

126. Smith, C.; Hill, A.K.; Torrente-Murciano, L. Current and future role of Haber-Bosch ammonia in a carbon-free energy landscape. Energy Environ. Sci. 2020, 13, 331-344. [CrossRef] 